\title{
Fleksibilitas Pemaknaan Wakaf Tunai di Indonesia: Studi terhadap Lembaga Filantropi dan Lembaga Keuangan
}

\section{HILMAN LATIEF, SYARIF AS'AD, MIFTAKHUL KHASANAH}

Ekonomi dan Perbankan Islam, Universitas Muhammadiyah Yogyakarta

Email : hilman.latief@gmail.com

\section{ABSTRACT}

This paper discusses cash waqf innovation in Indonesia by exploring the experience of Islamic financial institutions and Islamic philanthropy organizations. The increase of opportunity to gain public fund from the Muslim middle-class has lead to the dynamics and inovatove waqf (endowment) management. This article focuses on the socio-economi context that fueled the incease of cash waqf practice, and various innovative forms of Islamic phinathropy. This paper argues that the concept of cash waqf has been translated in various ways, and there have been different forms of cash waqf management. This suggests that people put much attention to ideas of maslahat (the benefit of society) in practicing cash waqf instead of simply rigidly following Islamic jurisprudential rule or positive law.

Keywords: cash waqf, Islamci jurisprudence, middle class, and financial institution

\section{ABSTRAK}

Artikel ini membahas tentang mekanisme pengelolaan wakaf tunai di Indonesia dengan melihat pengalaman lembaga keuangan syariah dan lembaga filantropi Islam. Semakin terbukanya praktik kesempatan untuk menggalang dana sosial di kalangan kelas menengah Muslim, menjadi praktik filantropi Islam semakin dinamis dan sangat inovatif. Artikel ini fokus kepada konteks sosial-ekonomi yang melatarbelakangi maraknya wakaf tunai di Indonesia, dan bentuk-bentuk inovasi pengelolaan filantropi Islam. Kesimpulan dari artikel ini menunjukkan bahwa praktik wakaf tunai di Indonesia sangat dinamis, tidak seragam, dan sangat lentur. Hal itu menunjukkan bahwa kemasalahatan lebih menjadi pertimbangan para pengelola dana wakaf tunai daripada aturan main ataupun aspek hukum Islam maupun hukum positif semata-mata.

Kata Kunci: wakaf tunai, hukum Islam, kelas menengah, lembaga keuangan 


\section{Pendahuluan}

Gagasan untuk menggali dan merevitalisasi konsep-konsep dasar filantropi Islam di Indonesia mulai mengemuka dan menemukan momentumnya setidaknya dalam satu dekade terakhir ini. Krisis ekonomi yang melanda Indonesia pada akhir tahun 1990an, mendorong umat Islam Indonesia untuk melirik kembali fungsi dan peran 'filantropi Islam', seperti zakat, sedekah dan wakaf, dalam mendorong perubahan sosial di Indonesia. ${ }^{1}$ Hal ini ditandai oleh munculnya lembaga filantropi Islam yang bertugas menggalang dana-dana sosial dari masyarakat, baik individual maupun kolektif, untuk kemudian disalurkan ke dalam pelbagai bentuk kegiatan yang memberikan manfaat bagi masyarakat, khususnya kaum miskin. ${ }^{2}$ Menjamurnya lembaga filantropi Islam yang mengelola zakat, sedekah dan wakaf dalam sepuluh tahun terakhir mengindikasikan tingginya antusiasme masyarakat dalam merevitalisasi tradisi filantropi Islam. ${ }^{3}$ Antusiasme tersebut dalam di lihat dalam tiga aspek aspek, yaitu 1) transformasi kelembagaan; 2) dinamika pendistribusian dana filantropi melaui programprogram sosial, serta 3) inovasi pada konsep-konsep dasar filantropi Islam yang melegitimasi penggalangan dana sosial dari masyarakat umum.

Pertama, 'transformasi kelembagaan' dalam aktivisme filantropi Islam di Indonesia ditandai dengan proses birokratisasi dan modernisasi pada lembaga filantropi Islam, termasuk lembaga pengelola ZISWAF (zakat, infak, sedekah dan wakaf) di Indonesia. Proses birokratisasi yang dimaksud adalah, kegiatan sosial keagamaan dalam masyarakat menjadi lebih terstruktur dan dikelola oleh sebuah organisasi yang memiliki sistem manajemen yang lebih baik sehingga akuntabilitas pengelolaan dana sosial menjadi lebih terukur dan terkontrol, baik akuntabilitas sumberdaya manusia, akuntabilitas manajerial, dan akuntabilitas pengelolaan keuangan. ${ }^{4}$

Kedua, pendistribusian dana-dana sosial oleh lembaga filantropi Islam saat ini, misalnya Dompet Dhuafa (DD), Rumah Zakat Indonesia (RZI), Dompet Peduli Umat-Daarut Tauhid (DPU-DT), Lazismuh, Al-Azhar Peduli dan sebagainya, sangat beragam, mulai pelayanan kesehatan buat keluarga tidak mampu, pemberdayaan ekonomi, pemberian beasiswa, dan pelatihan keterampilan praktis. Tidak hanya itu, lembaga-lembaga filantropi Islam saat ini berperan aktif dalam misi-misi kemanusiaan dan penanggulangan bencana di daerah rawan bencana maupun berpartisipasi dalam member bantuan (relief assistance) di lokasi konflik. ${ }^{5}$

Ketiga, inovasi pada konsep-konsep dasar filantropi Islam, seperti zakat dan wakaf telah dilakukan oleh berbagai lembaga keislaman di Indonesia. 
Pelaksanaan konsep 'zakat profesi' di Indonesia merupakan satu indikasi paling nyata dari inovasi tersebut. Mayoritas organisasi keagamaan di Indonesia mengadopsi konsep tersebut, meski dengan interpretasi yang berbeda-beda. Badan Amil Zakat (BAZ), sebuah lembaga yang disponsori pemerintah untuk mengelola dana sosial dari kaum Muslim, sebagai contoh, lebih banyak mengandalkan gagasan zakat profesi untuk memobilisasi dana dari pegawai negeri di tingkat kabupaten, povinsi, maupun nasional. ${ }^{6}$

Selaras dengan inovasi tersebut, konsep 'wakaf tunai' (waqf al-nuqud atau cash endowment) menjadi fenomena yang berkembang di Indoensia dalam dua dasawarsa terakhir ini. Praktik wakaf dengan uang tunai, uniknya, mendapat legitimasinya baik dari lembaga otoritas keagamaan seperti MUI (Majelis Ulama Indonesia)7 maupun Departemen Agama Republik Indonesia. Mengenai wakaf tunai ini, MUI mengeluarkan beberapa keputusan sebagai berikut: 1) yang disebut 'wakaf tunai' (waqf al-nuqud) adalah wakaf yang dilakukan oleh seseorang, lembaga maupun badan hukum dalam bentuk uang; 2) makna atau arti dari 'uang' yang dimaksud mencakup 'surat berharga'; 3) status hukum the wakaf tunai adalah boleh (jawaz); 4) wakaf tunai hanya bisa dipergunakan untuk sebuah keperluan yang diperbolehkan menurut Islam, dan 5) nilai utama dari uang dan keabadiannya harus terjaga dan tidak boleh dijual, didonasikan maupun diwariskan.

Artikel ini membahas aspek-aspek sebagai berikut: apa yang melatarbelakangi munculnya gagasan wakaf tunai tersebut dalam konteks sosial, ekonomi dan politik di Indonesia?; Bagaimana konsep wakaf tunai diadopsi dan dimplementasikan oleh lembaga-lembaga filantropi Islam di Indonesia?; Inovasi-inovasi seperti apakah yang dilakukan oleh pengelola wakaf tunai untuk mempermudah pelaksanaan wakaf tunia? Sebabagi studi kasus artikel ini membahas mekanisme pengelolaan wakaf uang yang dilakukan oleh Badan Wakaf Indonesia (BWI), Bank Syariah Mandiri, Tabung Wakaf Indonesia-Dompet Dhuafa dan Waqf Fund Management. Sebagi perbandingan, pengalaman ormas Islam seperti Muhammadiyah dan NU juga ikut dibahas.

\section{Dinamika Pengelolaan Wakaf Tunai}

Meskipun belum banyak, studi tentang wakaf tunai di Indonesia telah menarik perhatian beberapa sarjana dan peneliti, terutama yang berkecimpung dalam bidang sejarah ekonomi Islam. Di Indonesia, kajian wakaf tunai juga cukup mendapat perhatian para peneliti, salah satunya Irfan Abu Bakar dari CSRC-UIN Jakarta. Dalam artikelnya ia menelaah beberapa konsep dasar dalam 
fikih Islam yang dijadikan argument para ulama untuk mempraktikan wakaf tunai, yaitu konsep maslahah (public benefit) dan ta'amul (proper costum). Meski demikian, praktik wakaf di Indonesia belum disinggung sama sekali. ${ }^{8}$ Selain itu, secara konseptual Departemen Agama Republika telah melakukan pembahasan tentang pengertian wakaf tunai dan potensinya dalam pengembangan filantropi Islam dan pemberdayaan masyarakat di Indonesia. ${ }^{9}$ Pun, buku karya Edwin Nasution and Uswatun Hasanah (eds.), Wakaf Tunai, Inovasi Finansial Islam: Peluang dan Tantangan dalam Mewujudkan Kesejahteraan Ummat telah menelaah wakaf tunai dalam perspektif ekonomi Islam. ${ }^{10}$ Kedua produk akademik tersebut telah memberikan gambaran umum mengenai kemungkinan-kemungkinan melakukan inovasi di bidang lembaga keuangan Islam yang dapat mendorong peningkatan kapasitas lembaga filantropi dalam memperluas cakupan kegiatan sosial dan ekonominya.

Beberapa kajian empirik tentang wakaf tunai juga telah dilakukan oleh peneliti-peneliti lain. Mukhyar Fannai dalam artikel berjudul "Pengelolaan Wakaf Tunai" mengkaji tiga lembaga yaitu TWI (Tabung Wakaf Indonesia), PKPU (Pos Keadilan Peduli Umat) dan BMM (Baitul Maal Muamalat). Secara umum, studi tersebut menunjukkan bahwa wakaf tunai telah menjadi bagian dari program-program lembaga sosial Islam seperti TWI dan PKPU, dan pada saat yang sama telah dilakukan oleh lembaga keuangan seperti BMM. Mukhyar Fannai berkesimpulan bahwa proses penggalangan dana wakaf tunai yang dilakukan oleh BMM lebih efektif dibanding dengan dua organisasi lainnya yaitu TWI dan PKPU, karena BMM memiliki basis nasabah yang kuat dalam perbankan. Sementara ditinjau dari segi pengelolaan peruntukan dana wakaf tunai, ketiga organisasi tersebut memiliki banyak kesamaan, dintaranya menggunakan dana wakaf tunai untuk kepentingan sosial, pendidikan dan pemberdayaan ekonomi. ${ }^{11}$ Hal tersebut diperkuat dengan hasil penelitian Maya Maimunah yang melihat aspek pemberdayaan usaha kecil dan menengah dalam penggunaan wakaf tunai. ${ }^{12}$

Studi yang juga relevan dengan penelitian ini adalah karya Sri Handayani yang menulis tentang "Pelaksanaan Wakaf Tunai dalam Perspektif Hukum Islam setelah Berlakunya Undang-undang No. 41 Tahun 2004 tentang Wakaf di Kota Semarang." Dalam studi ini disebutkan bahwa pelaksanaan wakaf tunai, meskipun dalam perspektif hukum telah mendapatkan legitimasinya, namun secara operasional masih mendapatkan banyak hambatan. Hambatan tersebut antara lain peraturan teknis wakaf tunai/uang belum terintegrasi dengan wakaf secara umum, belum adanya kepastian hukum yang memadai yang 
dapat melindungi pewakaf maupun pengelola wakaf, wakaf tunai belum diatur secara terperinci.

Sebagai sebuah kajian rintisan, karya-karya tersebut di atas memberikan gambaran bahwa pelaksanaan wakaf tunai sangat dinamis dalam masyarakat Indonesia. Meski demikian, bagaimana perdebatan konseptual di kalangan ulama, akademisi dan praktisi mengenai konsep wakaf tunai ini, dan bagaimana pengalaman (baca: kesuksesan dan ketidaksuksesan) lembaga-lembaga filantropi Islam dan lembaga keuangan Islam di Indonesia dalam menggalang dana sosial melalui wakaf tunaimasih memberikan ruang untuk dianalisis lebih lanjut.

\section{Aspek Perundang-Undangan dan Pandangan keagamaan}

Tradisi wakaf sudah berlangsung ratusan tahun dan bahkan ribuan tahun lamanya, dan menggunakan istilah yang berbeda-beda. Hampir semua tradisi agama-agama memiliki konsep wakaf, dan hal itu sudah dipraktikan sepanjang peradaban manusia. Di kalangan Muslim sendiri, wakaf telah mentradisi begitu kuat. Hampir tidak ada lembaga-lembaga pendidikan, sosial dan keagamaan yang bisa lepas dari tradisi wakaf. Bahkan, perguruan tinggi-perguruan tinggi yang berada di Barat, sebagian berasal dari tradisi endowment, penyerahan asset dari seseorang kepada sebuah lembaga untuk dikelola dan dijaga keabadiannya. Bab ini membahas perkembangan wakaf uang di Indonesia, berikut tradisi wakaf di perkotaan dan pedesaan, aspek perundang-undangan, serta pandangan organisasi keagamaan tentang wakaf uang. Sebagai sebuah konsep yang relatif baru ditemukan dan diadopsi oleh kaum Muslim di Indonesia, wakaf tunai juga dipahami dan dilaksanakan secara beraneka ragam, dan dalam konteks tertentu, diperdebatkan oleh perbagai kalangan. ${ }^{13} \mathrm{Hal}$ ini bisa dipahami karena wakaf lebih identik dengan barang atau lahan dari pada uang. ${ }^{14} \mathrm{MUI}$ sendiri baru mengeluarkan fatwa tentang wakaf tunai pada tahun 2002, dan hal ini kemudian diikuti oleh lahirnya Undang-undang Wakaf pada tahun 2004.

\section{Dari Lahan dan Bangunan ke Uang Tunai}

Pertanyaan yang menarik untuk dikaji adalah mengapa wakaf uang muncul dan faktor apa yang melatar belakangi adanya pergeseran dari wakaf lahan/ bangunan menjadi wakaf tunai. Wujud kekayaan seseorang dan tingkat kekayaan atau kepemilikan asset oleh seseorang mengalami pergeseran dari waktu ke waktu. Penguasaan lahan yang luas menjadi simbol kekayaan atau 
kekuasaan atau pengaruh seseorang. Orang-orang kaya identik dengan kepemilikan banyak lahan, dari dulu hingga kini. Karena itu, bila kita melihat sejarah perkembangan wakaf, maka peran tokoh-tokoh tertentu sangat penting mewarnai berkembangnya tradisi wakaf yang kemudian menjadi tulang punggung di balik berkembangnya lembaga sosial, pendidikan dan kesehatan dalam komunitas Muslim.

Salah satu argumen yang dikemukakan pada bagian ini adalah bahwa tradisi wakaf tunai sebetulnya merepresentasikan fenomena tradisi Muslim perkotaan. Semakin menyepitnya asset dan proses pemerataan ekonomi yang terus tumbuh menjadi salah satu alasan mengapa praktik wakaf mengalami pergeseran. Di pedesaan, hampir sulit untuk ditemukan praktik wakaf tunai, pasalnya praktik wakaf lahan/bangunan masih sangat mungkin dilakukan. Biasanya wakaf lahan dilakukan oleh seseorang ketika mengawali pendirian bangunan tempat ibadah, bangunan lembaga pendidikan seperti pesantren atau madrasah, dan sebagainya. Karena itulah, tradisi wakaf ini sejatinya beriringan dengan perkembangan sebuah kawasan. Sebuah desa kecil dan terpencil dapat berkembang dengan cepat ketika seseorang mewakafkan tanahnya untuk dijadikan sebagai tempat berdirinya lembaga keagamaan dan pendidikan. Secara perlahan, desa tersebut berkembang dan semakin ramai. Harga tanah di pedesaan juga jauh lebih murah di pedesaan dibanding perkotaan. Oleh karena itu, sangat memungkinkan orang-orang di pedesaan untuk mewakafkan tanahnya yang luas guna kepentingan yang lebih besar.

Hal tersebut sangat berbeda ketika memasuki masyarakat perkotaan. Meski ketersediaan sumber daya ekonomi lebih banyak dan dinamis, masyarakat perkotaan juga menghadapi persoalan lain, yaitu keterbatasan lahan. Tanah di perkotaan juga dapat menjadi asset bisnis yang nilainya sangat tinggi. Keterbatasan masyrakat di perkotaan untuk menguasai lahan luas demi kepentingan sosial adalah sisi lain yang boleh jadi menstimulasi perkembangan atau inovasi dalam praktik wakaf. Hal ini setidaknya dapat dibandingkan dengan praktik zakat, dimana praktik zakat pertanian saat ini lebih kecil porsinya dibandingkan dengan zakat perdagangan ataupun zakat penghjasilan yang lain. Bila dalam praktik zakat terjadi bentuk inovasi dengan lahirnya "zakat profesi" atau "zakat gaji", yaitu zakat yang diambil dari penghasilan bulanan seorang Muslim yang terkena wajib zakat, maka di bidang praktik wakaf, "wakaf tunai" merupakan satu bentuk inovasi masyarakat perkotaan.

Sebagai sebuah "tadisi baru", wakaf tunai kini sudah mulai mendapatkan tempat yang lebih luas dalam masyarakat Indonesia. Hal itu dapat dilihat dari 
semakin banyaknya lembaga-lembaga sosial Islam dan bahkan lembaga keuangan Islam yang mulai menggunakan istilah wakaf uang/tunai dalam rangka menggalang dana-dana sosial dari masyarakat. Penggunaan wakaf tunai tidak jauh berbeda dengan wakaf yang lainnya, yaitu guna meningkatkan kesejahteraan masyarakat, memperkuat mutu pendidikan, serta untuk memajukan kegiatan ekonomi masyarakat. Memang, hingga hari ini belum diketahui secara pasti siapa penggagas awal wakaf tunai di Indonesia. Pasalnya, selama puluhan tahun, konsep wakaf lebih lekat atau identik dengan pengalihan asset berupa tanah dan bangunan. Mungkin, dua sasawarsa silam belum istilah wakaf tunai sangat tidak popular, karena bentuk kontribusi dana sosial secara tunai lebih identik dengan kegiatan sedekah.

Namun demikian, di Indonesia sudah banyak didirikan lembaga yang diberikan kuasa atau mengklaim memiliki kuasa untuk mengelola wakaf tunai. Salah satunya adalah Tabung Wakaf Indonesia (TWI), sebuah lembaga yang didirikan secara khusus oleh pegiat filantropi Islam, khususnya yang bergabung dengan Dompet Dhuafa, untuk mengelola wakaf uang. Lembaga ini berdiri pada tahun 2005 oleh Dompet Dhuafa, sebagai salah satu bentuk ekspansi dari aktivitas filantropi Islam yang dikelola oleh Dumpet Dhuafa. ${ }^{15}$ Dalam praktinya, TWI menerima pengelollan harta wakaf dalam bentuk tunai, yang antara lain berupa uang, emas, dinar \& dirham, serta perhiasan emas dan perak. Dengan demikian terdapat fleksibilitas di dalam pelaksanaan wakaf tunai di Indonesia, yang tidak semata-mata terkait dengan "uang tunai" tetapi lebih kepada barang atau "harta bergerak." Hal itu juga dilkaukan oleh lembaga-lembaga lain yang mengelola wakaf tunia di Indonesia, baik yang dikelola organisasi masyarakat sipil atau yayasan-yayasan Islam.

\section{Perkembangan Wakaf Tunai}

Secara historis disebutkan bahwa pada abad ke $16^{\text {th }}$ dan $17^{\text {th }}$, perdebatan di kalangan para ulama tentang wakaf uang untuk kepentingan sosial sudah terjadi. Pada masa Kekhalifahan Turki Utsmani, wakaf tunai sudah dipraktikkan secara luas dalam masyarakat Muslim dan praktik ini didukung pula oleh negara, disamping diperdebatkan oleh para ulama ahli hukum Islam. ${ }^{16}$ Sebagian ulama mengajukan pelbagai alasan dalam mendukung praktik wakaf tunai, salah satunya adalah terkait dengan praktik kebiasaan masyarakat (customary practice), ${ }^{17}$ yang mengindikasikan bahwa dana yang diwakafkan cukup popular pada waktu itu, dan secara hukum praktik ini diterima oleh sistem hukum sebelumnya. ${ }^{18}$ Pada masa pemerintahan Utsmani, namun tidak 
demikian halnya di negara-negara Arab seperti Mesir, wakaf tunai merupakan sumber kredit yang penting (an important source of credit). ${ }^{19}$ Sementara kalangan ulama yang menolak praktik ini, beranggapan bahwa tanah atau lahan berbeda dengan uang, sebab pada 'nilai' (value) tanah dan lahan tidak mengenal inflasi dan deflasi. Pada saat yang sama, prinsip 'keabadian' (perpetuity) yang memberika karakter pada objek-objek tidak bergerak seperti tanah tidak dapat diterapkan pada uang. ${ }^{20}$

Sebagai sebuah gagasan, memang wakaf tunai lebih sedikit ditemukan dalam literatur-literatur klasik. Setidaknya para ulama Imam madzhab, seperti Hambali, Hanafi, Maliki dan Syafii banyak memperdebatkan masalah wakaf dalam pelbagai aspeknya, mulai dari syarat-syarat-syarat wakaf maupun penggunaannya. Selain itu, perhatian para ulama juga lebih banyak kepada jenis harta benda yang "tidak bergerak" ketika membahas jenis harta wakaf. Muhammad Abid Abdullah Al-Kabisi dalam karyanya Ahkam al-Waqffi alSyariah al-Islamiyyah misalnya mengulas pelbagai bentuk pendapat yang dikemukan para Imam Madzhab terkait dengan wakaf. ${ }^{21}$ Abdullah Al-Kabisi menilai bahwa para Imam madzhab fikih Islam tidak konsisten dalam merumuskan pandangan mereka tentang wakaf. Artinya, telah terjadi pergeseran di kalangan para ulama tentang harta yang dapat diwakafkan.

Abdullah Al-Kabisi mencatat bahwa menurut Madzhab Hanafiyah, harta wakaf haruslah harta yang abadi dan kekal, dan oleh karena hanya benda yang tidak bergerak yang dapat diwakafkan, seperti tanah dan bangunan. Meski demikian, mereka juga berpendapat bahwa boleh saja harta yang bergerak diwakafkan selama ada dalil yang kuat yang mendukung pelaksanaan tersebut. ${ }^{22}$ Bahkan seorang ulama bernama Kamal bin Hammam sebagaimana digambarkan dalam Fathul Qadir dan dikutip oleh Abdullah Al-Kabisi, menyatakan bahwa kaum Muslim tidak diperkenankan mewakafkan satu bentuk harta yang mudah rusak dan musnah, seperti emas, perak makanan dan minuman. Dalam konteks ini yang dimaksud emas dan perak adalah mata uang dinar dan dirham. ${ }^{23}$ Bila pernyataan tersebut yang muncul, itu artinya bahwa sebelumnya tradisi wakaf tunai tersebut, tidak terlalu popular, setidaknya di tempat pada ulama mazhab Hanafiyah ini tinggal. Karena itu, sebagian ulama berpendapat bahwa pelaksanaan wakaf tunai dapat diterima bila memang lazim dipraktikkan — dan dapat diterima —oleh masyarakat. Oleh karena itu pelaksanaan wakaf tunai lebih merupakan kebiasaan yang berkembang dalam masyarakat. ${ }^{24}$ Sebagimana dikemukakan oleh Imam alMawardi dalam kitabnya Al-Hawi Al-Kabir bahwa Imam Syafii berpendapat 
bahwa wakaf uang dinar dan dirham, sebagimana yang dipraktikan atau menjadikan kebiasaan sebagian masyarakat Muslim di zamannya, adalah boleh. ${ }^{25}$

Dalam konteks inilah sebenarnya bagaimana tradisi baru tersebut muncul di Indonesia dan mengapa gagasan wakaf tunia baru muncul belakangan. Tentu saja, ada banyak alasan mengapa praktik wakaf tunai baru dilasanakan baru-baru ini saja, meski sebelumnya para filantropis di Indonesia aktif memberikan donasi kepada yayasan-yayasan sosial pendidikan dan keagamaan, dengan melalui konsep sedekah atau infak, dan bukan wakaf. Dalam pandangan penulis, sebagaimana akan dijelaskan pada bagian berikutnya dari tulisan ini, fenomena wakaf tunai adalah fenomena perkotaan. Pergeseran model mata pencaharian yang dimiliki seseorang saat ini sudah berubah, tidak hanya didasarkan pada penguasaan lahan-lahan yang luas sebagaimana yang dilakukan oleh masyarakat pedesaan, tetapi juga penguasaan keterampilan dan teknologi.

Dalam tiga dasawarsa terakhir, jumlah kaum kelas menengah Muslim Indonesia memang terus berkembang. Munculnya kota-kota baru dan kelas menengah baru menjadikan memberikan ruang aktivisme keagamaan, khususnya keislaman yang juga semakin dinamis. Dengan kata lain, kelas menengah Muslim telah menjadi sebuah entitas baru yang mewarnai perubahan sosial dan politik di Indonesia. Hal ini ditandai dengan munculnya berbagai organisasi Islam di kalangan professional Muslim. Lahirnya ICMI pada awal tahun 1990an merupakan satu indikasi dari semakin menguatnya kelas menengah Muslim di Indonesia. ICMI bukan saja telah berperan sebuah ruang untuk memperkuat kohesivitas kelas menengah Muslim, tetapi untuk mempercepat mobilitas vertikal di bidang politik dan ekonomi pada masa Orde Baru. ${ }^{26}$

Ruang-ruang politik dan ekonomi semakin terbuka dan kelas menengah Muslim memiliki cukup keleluasaan untuk melakukan pelbagai inovasi dalam praktik sosial-ekonomi yang inspirasi gagasan keagamaan, termasuk praktik wakaf. Kelas menengah adalah kelompok sosial yang secara ekonomi memang bersifat moderat dan berada di tengah. Mereka menjadi kelompok sosialekonomi yang dominan yang memiliki banyak peran dalam struktur pemerintahan, bidang swasta dan bahkan di sektor informal. Semakin menguatnya peran kelas menengah di Indonesia, boleh jadi mempengaruhi dan membentuk model-model baru praktik keislaman di Indonesia, serperti penggunaan zakat melalui sms dan internet, serta wakaf yang tidak lagi 
dilakukan melalui penyerahan asset, tetapi juga dalam bentu "tunai" dalam jumlah yang jauh lebih kecil secara nilai nominal di banding penyerahan asset berupa lahan dan bangunan.

\section{Wakaf Tunai: Wakaf Versi Kelas Menengah}

Salah satu argument yang bisa diajukan dalam tulisan ini adalah bahwa pada tingkat akar rumput, praktik wakaf tunai boleh jadi merupakan praktik wakaf Muslim kelas menengah perkotaan. Ada beberapa faktor yang dijadikan landasan untuk memperkuat argument di atas.

Pertama, faktor sosial-ekonomi. Secara ekonomi, sebagaimana pernah disinggung sebelumnya, peran kelas menengah dalam penguasaan asset tidak lah terlalu besar. la berada di bawa kelas menengah atas yang penghasilannya jauh lebih besar. Namun, kelas menegah atas (upper-middle class) lebih kecil jumlahnya. Keterbatasan dalam penguasaan kapital atau modal yang dimiliki oleh kelas menengah menjadikan asset yang dimiliki oleh individu-invidu kelas menengah saat ini juga terbatas, terutama di kalangan pegawai atau pekerja, seperti guru, dosen, pedagang, PNS, dam lain-lain. Oleh karena itu, secara ekonomi kelas memiliki kehidupan yang cukup dan bebrnading antara penghasilan yang mereka dapatkan serta kebutuhan yang harus mereka penuhi.

Kedua, faktor sosial-politik. Kelas menengah juga menguasai memiliki pernah aktif di sektor politik. Mereka menjadi birokrat, pagawai, aktivis partai politik, pegiat sosial, dan aktivis keagamaan. Saat ini, kekuatan kelas menengah dalam mentransformasikan Islam dalam ranah publik sangat besar. Hal itu bisa ditandai dengan munculnya pendukung partai-partai keagamaan di kalangan muda, dan semakin maraknya kegiatan-kegiatan keislaman di ruang publik. Pada saat yang sama, kelas menegah, dengan jaringan yang dimilikinya mampu membuka keran politik yang mengakomodasi kepentingan masyrakat Muslim, seperti munculnya peraturan daerah (PERDA) yang terkait dengan keagamaan, seperti peraturan tentang pelaksanaan zakat, undang-undang tentang halal, dan sebagainya.

Ketiga, faktor sosial-keagamaan. Indonesia dalam dua puluh tahun terkahir ini mengalami proses Islamisasi yang kuat dalam pelbagai sektor kehidupan. Kelas menengah sebagai kelompok dominan tidak saja menjadi kelompok yang menentukan bentuk dan karakteristik sosial-politik masyarakat Indonesia, tetapi juga membentuk ekspresi-ekspresi sosial, budaya dan politik Islam. Pengajian-pengajian kelas menengah semakin marak, lembaga-lembaga pengelola zakat terus bertambah, dan lembaga keuangan Islam memiliki produk 
yang semakin beragam, termasuk melayani pengelolaan wakaf tunai.

Selain hal-hal di atas, menunjukkan perlu ditekankan bahwa kelas menengah Muslim di Indonesia bersifat dinamis dan menerima keterbukaan dalam melakukan inovasi praktik keagamaan, khususnya yang terkait di bidang sosialekonomi. Jelas, bahwa praktik wakaf tunai adalah salah satunya. Hal ini dapat dibandingkan dengan fleksibilitas praktik ekagamaan yang terkait dengan kegiatan ekonomi, seperti meningkatnya jumlah perbankan Islam dengan segala jenis model transaksinya (mudharabah, musyarakah, dll), praktik simpan pinjam dalam BMT, pembuatan lembaga pegadaian syariah dan sebagainya.

\section{Perkembangan Regulasi}

Seiring dengan berkembangnya konsep negara-bangsa, khususnya setelah kejatuhan kekhilafan Islam yang juga beriringan dengan munculnya kekuatan kolonialisme Barat di dunia Islam, khususnya pada abad ke 19 dan awal abad ke 20, adminsitrasi wakaf menjadi perhatian pemerintah kolonial. Hak ini bisa dilihat pada pengaruh hukum Perancis di Jordan dan Mesir, Inggris di India-Pakistan ${ }^{27}$ dan Malaysia, ${ }^{28}$ dan juga Belanda di Indonesia. ${ }^{29}$ Dalam sebuah studi tentang wakaf yang filakukan di Zanzibar, disebutkan bahwa pemerintah kolonial Inggris memberikan dampak terhadap pengelolaan wakaf dalam wilayah Kesultanan Zanzibar. Kebijakan-kebijakan yang dikeluarkan oleh pemerintah kolonial Inggris mengenai wakaf di Zanzibar dapat dikatakan sebagai bentuk dari kombinasi pelbagai motif yang satu sama lain kadang saling bertentangan. Wakaf, acap kali terkait dengan kepentingan-kepentingan para elit lokal yang perannya membentuk kerjasama dengan pemerintah kolonial Inggris sangat menentukan kekuatan politik kolonial di Kesultanan tersebut. ${ }^{30}$ Regulasi yang dibuat oleh pemerintah lolonial pada umumnya terkait dengan objek-objek wakaf, khususnya wakaf dalam bentuk harta benda tidak bergerak seperti tanah dan bangunan yang digunakan untuk kepentingan umum. Pemerintah Kolonial Belanda, misalnya, memberikan perhatian yang cukup besar untuk pengelolaan adminsitrasi wakaf, namun tidak demikian halnya untuk praktik zakat di kalangan Muslim Nusantara pada masa kolonial. ${ }^{31}$

Meski demikian, prakti wakaf di Indonesia, seperti halnya di negara-negara Muslim lainnya, berbeda dengan praktik zakat. Praktik wakaf, dalam banyak pengalaman di lapangan, kerap diwarnai oleh perseteruan antara orang yang berwakaf (waqif) dan wahli waris atau kerabat keluarganya yang boleh jadi tidak setuju dengan keputusan pemilik harta untuk mewakafkan harta bendanya. Ahli waris darti pewakaf kerap pula berbeda pendapat atau berselisih 
paham dengan, pengelola harta wakaf (nazir), dan juga penerima manfaat wakaf. Karena itu, pembatalan proses wakaf seringkali terjadi. ${ }^{32}$

Pemerintah kolonial Belada mengeluarkan Surat Edaran (yang dapat ditemukan dalam Bijblaad 1905 Nomor 6169; Bijblaad 1931 Nomor 125/3; Bijblaad 1934 Nomor 13390; Bijblaad 1935 Nomor 13480 tentang Toezicht op den bouw van Muhammedaansche bedehuizen) yang berisi tentang perintah untuk mendaftarkan seluruh asset dalam bentuk bangunan, khususnya Masjid yang berasal dari wakaf, dengan tujuan untuk mengkarifikasi status kepemilikan lahan dan bangunan. Mekansime tersebut diterapkan untuk mengetahui apakah proses penyerahan asset (wakaf) tersebut bertentangan dengan hukum adat ataukan tidak. ${ }^{33}$

Setelah Hari Kemerdekaan, wakaf diatur oleh-dan digabungkan denganHukum Agraria Noomor 5 Tahun 1960 tentang Undang-undang Pokok Agraria, yang masih mengatur status kepemilikan dan keabadian harta tidak berberak. ${ }^{34}$ Segera setelah itu, Peraturan Pemerintah Nomor 28 Tahun 1977 tentang Perwakafan Tanah Milik memperkuat payung hukum dari sistem perwakafan di Indonesia. Peristiwa yang bersejarah dimulai setelah era reformasi ketika pemerintah mengeluarkan Undang-Undang No 41 Tahun 2004 tentang Waqf. ${ }^{35}$ Terdapat dua alasan di balik penetapan undang-undang ini wakaf ini: pertama, untuk mendorong terwujudnya kesejahteraan masyarakat melalui aksi-aksi kedermawanan dan gerakan sedekah/wakaf; dan kedua, untuk menertibkan administrasi wakaf di Indonesia.

Undang-undang Wakaf bertujuan untuk memberikan payung hukum terhadap praktik-praktik wakaf di kalangan Muslim di Indonesia, memperluas cakupan harta benda yang dapat diwakafkan, memperluas cakupan penerima wakaf, memelihara dan melindungi status harta yang diwakafkan, dan memberikan dasar hukum untuk menyelesaikan sengketa tentang harta wakaf. ${ }^{36}$ Pada bagian 6 dari Undang-undang ini, khsususnya pasal 16, disebutkan bahwa harta benda bergerak, yang menjadi landasan wakaf tunai, yang dapat diwakafkan adalah, uang tunai, logam mulia, surat berharga, kendaraan, kekayaan intelektual, hak sewa dan harta benda lainnya yang sesuai dengan syariah serta hukum yang berlaku di Indonesia.

Secara khusus, pasal-pasal khusus tentang wakaf tunai dapat ditemukan dalam Undang-undang wakaf ini, dimana harta benda bergerak, khususnya uang, harus di salurkan proses wakafnya melalui lembaga keuangan syari'ah yang telah ditunjuk oleh Kementeriaan Agama Republik Indonesia (Pasal 28). Orang yang berwakaf (waqif), kemudian akan menerima Sertifikat Wakaf dari 
lembaga keuangan yang telah ditunjuk tadi (Pasal 28, ayat 2). Untuk itu, dapat dikatakan bahwa praktik wakaf tunai di Indonesia memang selaras dengan perkembangan lembaga keuangan Islam, mulai dari BMT sampai bankbank Islam. ${ }^{37}$ Oleh karena itu, tidak mengherankan bila wakaf tunai dapat dilihat sebagai salah satu inovasi dari lembaga keuangan Islam.

Dalam konteks nasional, segera setelah dikeluargkannya fatwa oleh MUI dan Undang-Undang Wakaf, beberapa lembaga yang secara khusus mengelola harta wakaf tunai mulai bermunculan. President Susilo Bambang Yudoyono kemudian meluncurkan Badan Wakaf Indonesia-BWI) pada 8 Januari 2010. BWI meyakini bahwa wakaf tunai akan membawa pada tahap baru peningkatan kesejahteraan masyarakat, dan mengurnagi praktik meminta-minta. Singkat kata, penggunaan wakaf tunai untuk investani bisnis akan mengubah budaya bersedekah di Indonesia dengan mentalitas kewirausahaan. Presiden Yudoyono pada waktu itu juga menyertakan sebagain harta yang dimilikinya sebagai bentuk dukungan praktik wakaf di Indonesia.

\section{Skema Pengelolaan Wakaf Tunai Oleh Lembaga Filantropi Islam}

\section{Praktik Wakaf Tunai}

Praktik wakaf tunai di Indonesia sesungguhnya didasarkan pada Peraturan Pemerintah (PP) Nomor 42 Tahun 2006, yang di dalamnya memuat beberapa hal antara tentang peran lembaga keuangan syariah yang dapat berperan sebagai nadzir untuk harta wakaf tunai. Ditunjuknya LKS sebagai salah satu pengelola dana wakaf tunai oleh pemerintah adalah untuk menjaga bahwa uang yang telah terkumpul aman, tidak hilang dan tentu saja tidak habis pakai. Sementara itu, bila dana wakaf tunai akan diintestasikan di luar LKS, maka investasi tersebut juga harus diasuransikan melalui lembaga asuransi syariah. Meski demikian, tidak semua lembaga keuangan syariah diberikan wewenang untuk mengelola wakaf tunai. Kementerian Agama Republik Indonesia telah menunjuk beberapa lembaga keuangan untuk mengelola wakaf tunai, yaitu Bank Muamalat Indonesia (BMI), Bank Syariah Mandiri (BSM), Bank Mega Syariah (BMS), Bank BNI Syariah dan Bank DKI Syariah.

Sebagaimana dikemukakan sebelumnya, mekanisme pelaksanaan wakaf tunai sudah ditentukan oleh BWI (Badan Wakaf Indonesia). BWI berperan dalam mempermudah proses pelaksanaan wakaf tunai bai kaum Muslim di Indonesia. Berbeda dengan lembagapengelola wakaf tunai lain, sebagaimana 
dijelaskan pada bagian sebelumnya, BWI telah menetapkan standar tersendiri tentang jumlah minimal dana wakaf tunai yang bisa diterima. Mekanisme wakaf tunai yang ditentukan oleh BWI dapat dilihat dalam skema berikut ini.

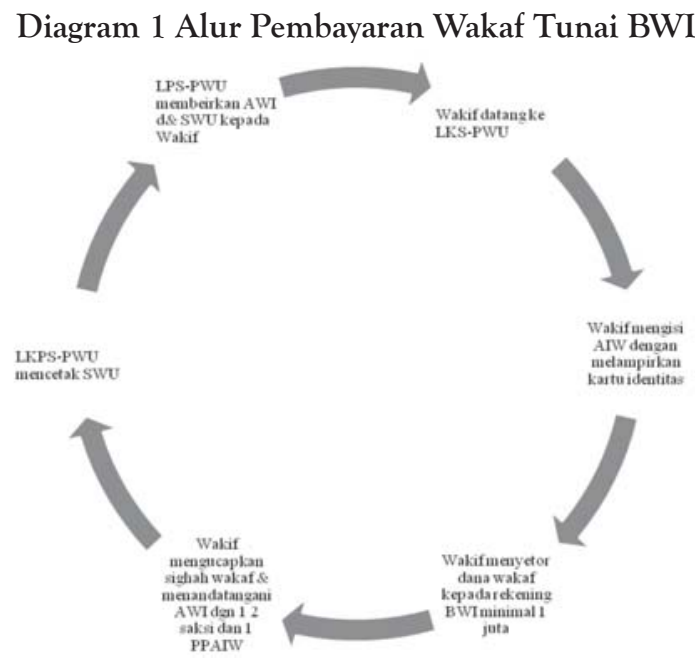

\footnotetext{
MAKNA SINGKATAN

AIW: Akta Ikrar Wakaf

SWU: Sertifikat Wakaf Uang

LKPS-PWU: Lembaga Keuangan Syariah Penerima Wakaf Uang

PPAIW: Pejabat Pembuat AIW
}

Dengan mekansime yang dirumuskan oleh BWI, maka calon wakif di kalangan Muslim Indonesia diberikan kemudahan dalam banyak aspek, antara lain: 1) calon wakif dapat melaksanakan wakaf tunai dimana saja mereka berada selama dapat melakukan transfer atau menyetorkan dana kepada bank (lembaga keuangan syariah) yang telah ditunjuk; 2) calon wakif dapat menyetorkan kapan saja dana yang mereka miliki sebagai bentuk wakaf tunai; 3) calon wakif diberikan keyakinan bahwa dana yang mereka wakafkan akan terjamin keabadiannya.

Meskipun demikian, ada beberapa catatan dari mekanisme pelaksanaan wakaf tunai seperti yang dilakukan oleh BWI, yaitu: 1) wakaf tidak terlalu mengerti bagaimana penggunaan dan peruntukan wakaf tunai yang mereka setorkan melalui bank; 2) wakif juga tidak terlalu mengerti secara spesifik dimana dana yang mereka setorkan itu akan digunakan; 3) wakif juga tidak dapat tahu secara persis kapan dana yang dia wakafkan itu akan digunakan serta; 4) wakif tidak memahami bentuk investasi apa dan keuntungan apa 
yang akan diperoleh dari dana wakaf tersebut. Hal inilah yang kemudian mendorong lembaga-lembaga masyarakat sipil atau lembaga filantropi Islam yang lain melakukan "inovasi" lain dalam pelaksanaan wakaf tunai. Inovasi yang dimaksud salah satunya adalah membuat skema-skema yang lebih sederhana dalam melaksanakan praktik wakaf tunai baik yang sesuai maupun tidak dengan perundang-undangan wakaf.

\section{Pengelolaan Wakaf Tunai oleh Lembaga Filantropi Islam}

\section{Tabung Wakaf Indonesia (TWI)}

TWI adalah salah satu lembaga filantropi Islam yang paling awal mengelola wakaf tunai di Indonesia. TWI merupakan satu badan khusus pengelola wakaf yang berafilisasi pada lembaga filantropi Islam nasional di Indonesia, Dompe Dhuafa. Bahkan TWI berdiri dan mengelola wakaf tunai sebelum undangundang wakaf yang memuat aturan tentang wakaf tunai ada. Program wakaf tunai yang dikelola oleh TWI adalah wakaf investasi. ${ }^{38}$ Yang dimaksud investasi dalam konteks ini adalah dana-dana yang terkumpul oleh TWI digunakan untuk membiayai kegiatan-kegiatan ekonomi indtustri kecil dan menengah, pembiayaan BMT dan sektor bisnis lainnya, untuk kemudian keuntungan yang diperoleh digunakan untuk kegiatan produkstif serta pengembangan masyarakat. ${ }^{39}$ Tidak hanya itu, Inovasi TWI dapat juga dilihat dari upayanya menerima wakaf saham dari PT. Bank Muamalat yang deviden-nya harus digunakan untuk kepentingan sosial sosial dan pengembangan masyarakat, dan bukan untuk diinvestasikan lagi. ${ }^{40}$

\section{Diagram 2 Alur Pembayaran Wakaf Tunai TWI}

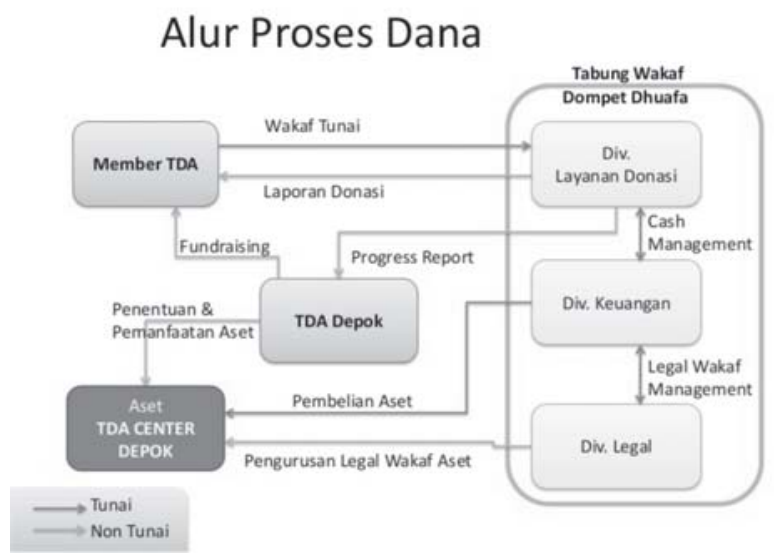


Di dalam pelaksanannya TWI menetapkan mekanisme yang tidak jauh berbeda dengan BWI. Dalam hal ini, sertifikat wakaf tunai bisa diperoleh bila wakif menyerahkan dana minimal satu juta rupiah.

\section{Waqf Fund Management-Jakarta}

Waqf Fund Management (WFM) adalah salah satu lembaga filantropi Islam di Indonesia yang diperuntukkan mengelola dana-dana wakaf dalam bentuk tunai. Sesuai namanya, Waqf Fund yang berarti wakaf tunai adalah sebuah yayasan yang cukup awal muncul di Indonesia untuk mengelola wakaf tunai. WFM menempatkan diri sebagai "lembaga investasi sosial pengelola dana wakaf dan wakaf produktif." Sejak kemunculannya, WFM melakukan banyak inovasi dalam menggalang dana wakaf guna mendanai proyek-proyek sosial. Inovasi tersebut dilakukan guna memfalitasi masyarakat dalam berwakaf dan karena itu membuat program wakaf yang paling sederhana dan mudah dilakukan oleh masyarakat, dengan menawarkan gerakan wakaf Rp. 1000 sehari atau sebulan sejumlah Rp. 30.000.

Dari model penawaran wakafnya, terlihat jelas bahwa tujuan utama yang dilakukan dari gerakan wakaf Rp. 1000 sehari adalah untuk membangun kesadaran dalam masyarakat luas tentang pentingnya berwakaf. Prinsip yang dibangun gerakan ini bukan semata-mata berbicara tentang bagaimana sebuah praktik wakaf dilakukan, melainkan juga bagaimana wakaf produktif bisa digelorakan dan menjadi bagian partisipasi masyarakat Muslim. Untuk menarik perhatian dari publik, pada tahun 2009, lembaga ini mengkampanyekan program wakaf produktif berupa Program bantuan bagi 1000 Anak Yatim, Program 1000 sarjana dari keluarga miskin, Program 1000 Usaha Kecil Kreatif Keluarga Miskin, Program 1000 haji bagi pengelola masjid dan aktivis keagamaan, dan program 1000 jaringan masjid digital. ${ }^{41}$ Tentu saja, dilihat dari jenis program yang ditawarkan, kita akan melihat banyak perbedaan dari jenis wakaf "konvensional" lainnya. Apa yang disebut dengan wakaf produktif, konsepnya tidak jauh berbeda dengan zakat produktif dimana dana yang diperoleh digunakan untuk membiayai proyek-proyek sosial. Beda antara zakat produktif dan wakaf produktif adalah pada model pengelolaan dana awalnya, dimana dana wakaf diinvestasikan terlebih dahulu sebelum digunakan untuk membiayai proyek sosial. ${ }^{42}$

Tentu saja, untuk menjalankan program wakaf tunai ini, WFM bekerjasama dengan lembaga-lembaga yang sudah memiliki akses dan jaringan serta sistem 
mobilisasi yang memadai, yaitu lembaga keuangan seperti Bank BNI Syariah dan Asuransi Bumi Putra Syariah. Penggunaan lembaga perbankan atau lembaga keuangan Islam sebagai mitra oleh WFM karena lembaga keuangan syariah memiliki instrumen untuk memobilisasi dana khususnya dari kalangan kelas menengah. Dalam penjelasnnya, Guntur S. Makardika, Managing Director dari Waqf Fund Management, menjelaskan bahwa kerjasama ini dilakukan dalam rangka melakukan pendidikan kepada anak-anak sekolah tentang pentingnya berderma. Namun dana yang diperoleh tidak digunakan secara langsung melainkan diinvestasikan melalui lembaga asuransi tersebut. Artinya, para siswa belajar berderma dan pada saat yang sama akan mendapatkan proteksi asuransi, dan dana yang telah diinvestasikan akan kembali guna disalurkan untuk program beasiswa dan sebagainya.

\section{Wakaf Tunai dan Ormas Islam Indonesia}

Sebagai sebuah tradisi yang sedang berkembang, wakaf tunai telah menjadi pembahasan khusus beberapa lembaga keagamaan di Indonesia. Forum-forum seminar, konferensi dan workshop telah diselenggarakan untuk membahas masalah ini, begitu pula dengan kementeriaan keagamaan. Meskipun demikian, kajian hukum mengenai wakaf tunai tidak terlalu intensif di lakukan oleh ormas, dan tidak banyak perdebatan yang kuncul. Hal ini berbeda bila kita bandingakan dengan lahirnya gagasan tentang zakat profesi atau zakat gaji. Zakat profesi telah diperdebatkan oleh banyak kalangan karena secara konseptual, kaum Muslim, khususnya para ulama, memliki pandangan yang berbeda tentang zakat, apakah sebagai bentuk ibadah mahdhah yang tidak perlu 'inovasi' ataukah ibadah maliyah ijtima'iyah semata-mata yang fleksibel untuk dimodifikasi. ${ }^{43}$

Sementara itu, konsep wakaf sendiri dalam hukum Islam tidak seketat atau sekuat doktrin tentang zakat. Sehingga, munculnya persepsi di kalangan Muslim pada umumnya bahwa inovasi dalam praktik wakaf lebih bisa mudah diterima. Selain itu, pelaksanaan wakaf yang bersifat kerelawanan menjadi permasalahn wakaf tidak terlalu menjadi persoalan yang diperdebatkan di kalangan Muslim, berbeda dengan hukum zakat yang diwajibkan. Meskipun demikian, di dalam wakaf terdapat prinsip-prinsip yang lebih tegas yang harus dipegang, khususnya mengenai keabadian harta wakaf, dan dalam aspek itulah para ulama membahas hal-hal dalam wakaf tunai.

Terdapat beberapa pandangan umum tentang wakaf tunai di kalangan ulama, yaitu membolehkan, tidak membolehkan dan membolehkan dengan 
syarat. Pendapat yang membolehkan biasanya disandarkan pada prinsip keabadian harta, apakah itu harta bergerak maupun bergerak. Tidak ada persoalan apakah wakaf itu berbentuk tunai ataupun lahan, selama harta itu tetap abadi maka diperbolehkan. Pendapat ini dipegang oleh ulama Hanafiyah dan Hanabilah. Sedangkan yang menolak pada umumnya berpendapat bahwa wakaf tunai secara fisik hartanya tidak abadi, karena ketika digunakan maka uang menjadi habis, dan karena itu tidak sesuai dengan prinsip keabadian harta yang menjadi landasan praktik wakaf. Tetapi tidak sedikit juga yang menunjukan kebolehan praktik wakaf tunai karena alasan kemaslahatan. ${ }^{44}$ Agaknya, di dalam praktiknya, saat ini pendapat ketiga menjadi banyak pegangan para pelaku praktik wakaf tunai di Indonesia saat ini.

\section{Muhammadiyah}

Muhammadiyah sendiri melalui Majelis Tarjih dan Tajdid tidak mengeluarkan fatwa khusus tentang wakaf tunai. Meksipun demikian, diskusi-diskusi oleh para ulama di kalangan Muhammadiyah di pelbagai daerah kerap dilakukan. Prof. Syamsul Anwar, Ketua Bidang Tarjihdan Tajidid Pimpinan Pusat Muhammadiyah mengatakan bahwa saat ini belum ada pembahasan khusus terkait wakaf tunai. ${ }^{45}$ Pasalnya belum ada permintaan khusus dan wakaf tunai juga dianggap tidak menjadi kontroversi, baik di kalangan umat Islam Indonesia maupun di kalangan warga Muhammadiyah sendiri. Selain itu, fatwa yang telah dikeluarkan MUI telah dianggap cukup untuk menjadi landasan umum tentang pelaksanaan wakaf tunai di Indonesia. Pada Buku Tanya Jawab Agama yang merupakan kumpulan fatwa-fatwa Tarjih Muhammadiyah, tidak satupun pembahasa wakaf tunai. Beberapa pertanyaan-pertanyaan keagamaan yang dilontarkan jamaah Muhammadiyah yang kemudian dijawab oleh majelis tarjih Muhammadiyah tidak satupun yang mempertanyakan tentang wakaf tunai.

Yang jelas salah satu program utama dari Majelis Wakaf dan Kehartabendaan Pimpinan Pusat Periode 2010-2015 adalah "Mengoptimalkan Pengembangan WAKAF dalam bentuk Wakaf tunai dan Wakaf Produktif sebagai benteng atas problem kemiskinan, keterbelakangan dan kebodohan pada masyarakat marjinal." Dalam konteks kemaslahatan pula, agaknya, Muhammadiyah tidak terlalu mempersoalkan pelaksanaan wakaf tunai secara lebih jauh. Wakaf tunai dipandang dapat memberikan manfaat untuk mendorong agenda-agenda organisasi dalam mengentaskan kemiskinan dan kebodohan. Seperti halnya Muhammadiyah, kumpulan fatwa dari ormas Persatuan Islam maupun 
Nahdlatul Ulama yidak secara spesifik membahas wakaf tunai.

Di kalangan Muhammadiyah maupun ormas lainnya, wakaf tunai biasanya dilaksanakan untuk membiayai proyek-proyek pembangunan tempat-tempat ibadah maupun lembaga pendidikan. Tentu saja ini menjadi fenomena yang menarik sebab sebelumnya istilah wakaf tunai tidak digunakan untuk membiayai proyek-proyek pembangunan. Sebelumnya, istilah yang lazim digunakan untuk membiayai proyek pembangunan adalah infak atau sadaqah jariyah. Namun demikian, seiring dengan perkembangan sosial-ekonomi masyarakat yang lebih merata, maka model-model penggunaan wakaf pun dibuat selentur mungkin agar partisipasi masyarakat dalam wakaf tunai menjadi lebih luas. Hal ini bisa dilihat dari praktik yang dilakukan oleh Muhammadiyah di pelbagai daerah, sebut saja Kabupaten Karanganyar, Jawa Tengah.

Dalam rangka mendorong percepatan pembangunan lembaga pendidikan, pimpinan Muhammadiyah di Karanganyar melakukan penggalangan dana melalui konsep "wakaf tunai". Pimpinan Muhammadiyah setempat bermaksud menggalang dana 1 milyar rupiah melalui wakaf tunai pendidikan. Artinya dana yang diperoleh akan dipergunakan sebagai dana "wakaf tunai pendidikan", yang jumlah wakaf dari para wakifnya jumlahnya tidak ditentukan. Menariknya, "wakaf tunai" semacam ini para pimpinan Muhammadiyah setempat melakukan "inovasi", dengan menjalankan program wakaf melalui cara cicilan dengan jumlah nominal sukarela. ${ }^{46}$ Dalam konteks yang lain, LAZIS Muhammadiyah di Surabaya juga merancang program wakaf tunai secara lebih fleksibel, yaitu wakaf untuk mobil ambulance.

Kampanye Wakaf Tunai Lazismu

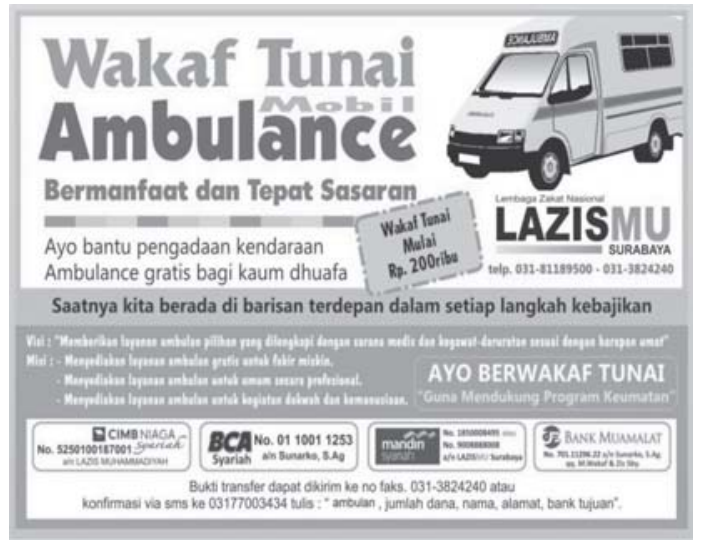

Fenomena lain dari pelaksanaan wakaf tunai dapat dilihat dari pengalanan 
amal usaha Muhammadiyah yang lain seperti Universitas Muhammadiyah Surakarta (UMS). Berbeda dari konsep wakaf tunai yang lain, UMS tidak menggalang dana dari individu-individu untuk digunakan sebagai wakaf tunai, melainkan dari hasil usaha yang dilakukan oleh UMS di sektor properti dan pasar uang. Lembaga Wakaf Tunai UMS mengelola dana hasil usaha untuk digunakan sebagai dana abadi lembaga yang dapat digunakan untuk pelbagai pengembangan amal usaha Muhammadiyah. UMS mengelola dana wakaf sebesar Rp. 120 Milyar dan bertambah sekitar 30 milyar pertahun. Menurut Prof. Bambang Setiaji, Rektor Universitas Muhammadiyah Surakarta, LWT UMS diproyeksikan menjadi bank khusus amal usaha Muhammadiyah yang dananya dapat ini dapat digunakan untuk pinjaman lunak bagi karyawan dan dosen, serta amal usaha Muhammadiyah yang membutuhkan suntikan dana bagi pengembangan lembaga. Selain itu, setiap bulannya, lembaga ini membayarkan zakat sebesar $5 \%$ dari keuntungan yang diperoleh. ${ }^{47}$

\section{Nahdlatul Ulama}

Sementara itu, di kalangan Nahdlatul Ulama (NU) wakaf tunai juga mulai popular. Pada tahun 2010, NU meluncurkan produk baru dari gerakan filantropi Islam, yaitu Lumbung Wakaf Nusantara (LWNU), yang secara khusus diamanahi untuk meningkatkan perolehan dan pengelolaan wakaf tunai. Proses yang dilakukan untuk wakaf ini tidak terlalu rumit, karena calon wakif hanya diharuskan menyetorkan sejumlah dana ke Bank yang telah ditentukan melalui rekening LPNU. Seperti halnya proses mobilisasi dana zakat, LPNU juga mecoba meningkatkan perolehan dana wakaf dari PNS dengan cara bekerjasama dengan pemerintah daerah di beberapa provinsi. Dalam prosesnya, dana yang terkumpul akan diserahkan kepada LKS yang telah ditentukan untuk kemudian dikelola dan diinvestasikan, dan hasil dari investasi tersebut akan digunakan untuk kepentingan sosial.

LWU menginvestasikan dana wakaf tunai yang diperoleh melalui pelbagai bentuk, antara lain investasi di bidang perhotelan melalui program Waqf Center. LWU merancang pembangunan hostel di lokasi tanah wakaf yang dikelola NU. Hostel ini akan dilengkapi fasilitas ruang diklat, ruang seminar, dan ruangruang komersial lainnya yang dapat disewakan kepada orang lain dan hasil dari investasi ini akan digunakan untuk mendampingi kegiatan pendidikan di kalangan dhuafa melalui bekerjasa dengan Lembaga Maarif Nandlatul Ulama dan pesantren-pesantren NU. Selain itu, program lainnya adalah Green Waqf, yaitu sebuah program yang dirancang untuk meningkatkan produktivtas lahan 
wakaf milik PB NU di kabupaten Brebes seluas 16 hektar. Lahan tersebut ditanami pohon jambon sebagai salah satu upaya untuk "memberdayakan ekonomi berbasis hutan desa". Hasil dari investasi ini juga digunakan untuk pengembangan pendidikan dan kesehatan. ${ }^{48}$

Sebagai mana di Muhammadiyah maupun ormas lainnya, pelaksanaan wakaf tunai di NU tidak ada yang tersentralisasi. Kehadiran LWNU tidak berarti bahwa seluruh dana wakaf tunai dikelola oleh lembaga ini. Dalam praktinya, masing-masing pimpinan cabang mengeloa dana wakaf di daerah juga mengelola wakaf tunai, tanpa harus melibatkan LWN maupun pebankan, karena disesuaikan dengan potensi yang terdapat di masyarakat tempat pengelola wakaf itu didirikan. Perlu dicatat bahwa bila ditelusuri lebih jauh model operasionalisasi dan pengelolaan wakaf tunai di Indonesia sangat beragam, baik yang sesuai dengan undang-undang maupun yang tidak sesuai. Begitu pula dengan prosedur yang ditetapkan oleh pengelola wakaf tunai. Tidak sedikit yang mengelola wakaf tunai seperti halnya mengelola infak atau sadekah biasa, tanpa menggunakannya untuk sebuah 'investasi' atau tanpa melibatkan lembaga keuangan sebagai lembaga penjamin.

\section{Peran Lembaga Keuangan Syariah}

Secara nasional lembaga keuangan syariah memiliki penting dalam tata kelola wakaf tunai. Pasalnya, beberapa Bank Syariah telah ditunjuk secara khusus oleh BWI menjadi lembaga yang otoritatif mengeluarkan sertifikat wakaf tunai. Pertanyaan yang muncul adalah apakah lembaga keuangan syariah berperan sebagai nadzir secara formil ataukah hanya menjadi lembaga penerima dana wakaf saja. Bila LKS berperan sebagai nadzir maka LKS berhak mengelola dana wakaf itu secara mandiri. Artinya LKS dapat menginvestasikan secara langsung dana wakaf itu di sektor bisnis, dan kemudian menjalankan sendiri program-program sosial dan pembangunan untuk masyarakat. Namun demikian, bila LKS berperan sebagai penerima wakaf tunai saja dalam arti sebagai perantara (intermediary), maka LKS tidak memiliki kewenangan untuk mengelola wakaf tunai, namun hanya fungsi peneriman dan memberikan skema pengamanannya saja. Oleh karena itu namanya disebut LKS-PWU. Sedangkan untuk pengelolaannya diserahkan kepada nadzir secara langsung untuk dikelola, dan dengan demikian LKS tidak berhak mengelola dana wakaf.

Menurut peraturan yang telah ditetapkan BWI, LKS-PWU hanya berperan menerima dan menyimpan dana wakaf saja, sedangkan untuk penggunaannya dilakukan oleh nadzir. Di dalam praktiknya, tidak semua konsep ideal wakaf 
dapat dilaksanakan dengan baik sesuai dengan mekanisme yang ditetapkan. Proses pembayaran wakaf tunai di LKS-PWU menjadi lebih sederhana lagi. Seperti saat pembayaran wakaf tunai, nazdir tidak dipersyaratkan hadir pada saat transaksi dan pembacaan akad wakaf di LKS-PWU, dan cukup diwakilkan kepada LKS-PWU. Hal ini dilakukan karena khawatir akan "merepotkan" nadzir. Dalam konteks inilah konsistensi pelaksanaan konsep wakaf bisa dilihat apakah sesuai dengan mekanisme wakaf normatif ataukah sudah terjadi proses modifikasi. ${ }^{49}$

Meski demikian, di dalam pelaksaannya, lembaga-lembaga keuangan syariah (LKS), termasuk BMT, juga ikut terjun menggeluti kegiatan filantropi seperti dengan menyediakan fitur-fitur pembayaran zakat. Hampir semua bankbank syariah memiliki mekanisme pembayaran zakat, terutama melalui mekanisme transfer ATM, sedangkan untuk wakaf tunai belum ada fitur-fitur khusus untuk pembayaran wakaf tunai, kecuali transfer yang dilakukan oleh wakif terhadap rekening nadzir atau pengelola wakaf.

\section{Kesimpulan}

Dari pembahasan di atas tentang pelaksanaan wakaf tunai di Indonesia yang dilakukan oleh lembaga keuangan dan filantropi Islam, dapat disimpulkan beberapa hal berikut: Pertama, maraknya pelasanaan wakaf tunai di Indonesia tidak bisa dilepaskan dari struktur atau kondisi sosial-ekonomi masyarakat Indonesia yang mulai membaik, khususnya dengan menguatnya kelas menengah Muslim di Indonesia. Muslim kelas menengah, baik yang berada di dunia kampus, birokrasi pemerintahan, di lembaga-lembaga bisnis, maupun dalam partai-partai politik. Indonesia sebagai negara Muslim terbesar di dunia telah menyaksikan perkembangan filantropi Islam yang kuat sejak dua puluh tahun terkahir. Menguatnya kelas menengah Muslim perkotaan telah menjadi salah satu faktor penting yang seiring sejalan dengan praktik wakaf tunai. Secara ekonomi, masyarakat Muslim kelas menengah dengan jumlah penghasilan yang juga menengah telah mencoba memberikan ruang dalam melaksanakan ajaran agama secara lebih fleksibel dan sesuai dengan kondisi perekonomian mereka, salah satunya dengan pelaksanaan wakaf tunai. Dalam konteks politik, konsep wakaf tunai juga diakomodasi dalam undang-undang wakaf dengan tanpa batasan aturan yang terlalu ketat, sehingga lembaga pengelola wakaf tunai bisa tumbuh subur di Indonesia.

Kedua, implementasi wakaf tunai di Indonesia tidaklah monolitik. Artinya, wakaf tunai telah dimodifikasi sedemikian rupa di pelbagai lapisan masyarakat, 
termasuk dalam lembaga keuangan, lembaga filantropi, dan yayasan-yayasan Islam. Oleh karena itu, meskipun terdapat undang-undang wakaf, Peraturan Presiden, dan juga peraturan yang dikeluarkan Badan Wakaf Indonesia, itu tidak berarti bahwa pelaksanaan wakaf tunai bersifat kaku dan dilaksanakan secara rigid atau kaku. Faktanya, sebagaimana yang digambarkan dalam penelitian ini, lembaga-lembaga filantropi Islam tidak memiliki pola yang seragam dalam melaksanakan tata kelola wakaf tunai, mulai dari mekanisme penggalangan, peruntukan, maupun transaksinya (akad). Tidak hanya itu, konsep pelaksanaan wakaf tunai menjadi lebih pragmatis dan dalam konteks tertentu tidak bisa dibedakan dengan sedekah atau infak yang biasa dilakukan. Lembaga filantropi Islam besar seperti TWI-DD barangkali salah satu lembaga yang mencoba melaksanakan wakaf tunai sesuai dengan aturan yang ada. Namun lembaga filantropi Islam dan juga ormas Islam bersikap lebih fleksibel sesuai dengan kapasitas dan potensi yang mereka.

Ketiga, dari studi kasus tentang pelaksanaan dalam lembaga filantropi Islam dapat pula disimpulkan bahwa langkah inovatif-pragmatis mewarnai pelaksanan hukum Islam di Indoensia. Kondisi sosial-ekonomi masyarakat setidaknya sangat berpengaruh dalam mendorong kaum Muslim untuk lebih fleksibel atau lentur dalam melaksanakan hukum-ukum Islam yang terkait dengan muamalah, khususnya lagi masalah sosial ekonomi. Dalam konteks tertentu bahkan dapat dikatakan bahwa konsep kemaslahatan menjadi salah konsep yang digunakan para pengelola filantropi Islam dalam melaksanakan hukum-hukum Islam di bidang muamalah. Fatwa-fatwa ulama baik yang tergabung di MUI tingkat pusat, maupun kajian-kajian hukum Islam yang dilakukan oleh para ulama di pelbagai daerah menjadi fakta yang menunjukkan bahwa hukum Islam di Indonesia berkembang secara sangat dinamis dan dalam konteks tertentu sangat pragmatis. Oleh karena, dilihat dari sisi perkembangan hukum Islam, "ijtihad-ijithad" baru mulai bermunculan yang mengindikasikan bahwa otoritas keagamaan di Indonesia tidak lagi ditentukan oleh figur sentral. Sebaliknya, otoritas ekagamaan telah terdistribusikan melalui ormas-ormas dan tokoh-tokoh lokal di masyarakat yang dianggap mampu memberikan legitimasi bagi pelaksanaan sebuah hukum Islam, terutama dalam wakaf tunai.

\section{Catatan Akhir}

1 Beberapa literatur tentang aktivisme filantropi Islam di Indonesia, lihat misalnya Hilman Latief, Melayani Umat: Filantropi Islam dan Ideologi Kesejahteraan Kaum 
Modernis (Jakarta: Gramedia, 2010); Amelia Fauzia, "Faith and the State: the History of Islamic Philanthropy in Indonesia”, PhD Dissertation, the University of Melbourne, (Melbourne-Australia, 2009).

2 Lihat Chaider S. Bamualim Islamic Philanthropy $\mathbb{E}$ Social Development in Contemporary Indonesia (Jakarta: CRCS UIN Syarif Hidayatullah, 2006); juga Studi Kasus dan Lembaga Wakaf dan Zakat di Indonesia (Jakarta: Center for the Study of Religion and Culture (CSRC), UIN Syarif Hidayatullah), 2005; Chaider S. Bamualim dan Irfan Abubakar (eds.), Revitalisasi Filantropi Islam: Studi Kasus Lembaga Wakaf dan Zakat di Indoensia (Jakarta: Center for the Study of Religion and Culture (CSRC), UIN Syarif Hidayatullah, 2005).

3 PIRAC, Muslim Philanthropy: Potential ad Reality of Zakat in Indonesia (Depok: Piramedia, 2005), 61-64.

4 Lihat PIRAC, Investing in Our Selves: Giving and Fundraising in Indonesia (Jakarta: Asian Development Bank, 2002); Saidi, Zaim et al. (eds.). Pola Penggalangan Dana Sosial di Indonesia: Pengalaman Delapan Belas Lembaga Sosial (Jakarta: Piramedia, PIRAC \& Ford Foundation, 2003).

5 Lihat Hilman Latief "Health Provision for the Poor: Islamic Aid and the Rise of Charitable Clinics in Indonesia," Journal of Southeast Asia Research, vol. 18, no. 3 (September 2010), 503-553; "Symbolic and Ideological Contestation over Humanitarian Emblems: The Red Crescent Movement in Islamizing Indonesia, Studia Islamika vol. 18, no. 2 (2011), h. 249-286.

6 Hilman Latief, “Contesting Almsgiving Post New Order Indonesia,” American Journal of Islamic Social Sciences, vol. 31, No. 1 (Winter 2014), h. 16-50.

7 Lihat Hasil Ijtima' Ulama Komisi Fatwa se-Indonesia III, 1430 H/2009 M.

8 Selain melakukan perbandingan padangan para ulama klasik, artikel ini secara konseptual menggambarkan beberapa produk yang mungkin bisa dihasilkan oleh praktik wakaf tunai, seperti 1) komobinasi antara qard al-hasan (benevolent loan) dan investasi produktif; 2) investasi mudarabah; 3) tabungan wakaf; dan 4) penggunaan hasil usaha dana wakaf. Lihat Irfan Abu Bakar, "Cash Waqf in Classical and Present-day Fiqh Discourse,” Kultur, Vol. 4, Number 1, (2009), h.121-134.

9 Departemen Agama RI, Strategy Pengembangan Wakaf Tunai di Indonesia (Jakarta: Direktorat Pemberdayaan Wakaf, 2008).

10 Lihat Mustafa Edwin Nasution and Uswatun Hasanah (eds.), Wakaf Tunai, Inovasi Finansial Islam: Peluang dan Tantangan dalam Mewujudkan Kesejahteraan Ummat (Jakarta: PKTTI-UI, 2005), h. 51-78.

11 Muhyar Fanani, "Pengelolaan Wakaf Tunai," Walisongo, Volume 19, Nomo2 1 (Mei 2011), h. 179-195.

12 Maya Maimunah, "Peran Wakaf Tunai dalam Pemberdayaan Usaha Kecil dan Menengah di Tabung Wakaf Indonesia, Skripsi, UIN Syarif Hidayatullah, 2011.

13 Lihat Rakhmat Djatnika, "Les wakaf ou 'bien de mainmorte’ aİ Java-est: eitude diachronique," Archipel (1985), h. 121-136

14 Dalam konteks sosial-politik di Indonesia, sejak tahun 1960an dan 1970an pemerintah mengatur perihal wakaf ini melalui pelbagai perundangan-undangan 
yang ada. Undang-undang Pokok Agraria No. 5 Tahun 1960, yang mengatur tentang wakaf benda tidak bergerak Lihat UU No 5 Tahun 1960 tentang Undangundang Pokok Agraria, Bab XI tentang Hak-hak Tanah untuk keperluan sosial dan keagamaan, pasal 49, dan Peraturan Pemerintah Nomor 28 Tahun 1977 tentang Perwakafan Tanah Milik.

15 http://tabungwakaf.com/profil-tabung-wakaf-indonesia/

16 Murad Cizakca, "Ottoman Cash Waqfs Revisited: the Case of Bursa 1555 1823," working paper, Foundation for Science, Technology and Civilization, FSTC, 2004; versi lain dari artikel ini lihat Journal of the Economic and the Social History of the Orient, 38, 3 (1995); dan An History of Islamic Foundations in the Islamic World from the Seventh Century to the Present (Istanbul: Bogazici University Press, 2000).

17 Jon E. Mandaville, "Usurious Piety: The Cash Waqf Controversy in the Ottoman Empire," International Journal of Middle East Studies, No. 10 (1979), h. 289.

18 Amy Singer, Constructing Ottoman Beneficence: An Imperial Soup Kitchen in Jerusalem (Albany: A State University of New York Press, 2002), 18.

19 Arif Ali Khan at al. (eds.), Encyclopaedia of Islamic Law: Law of Waqf in Islam (New Delhi: Pentagos Press, 2006), h. 5.

20 Jon E. Mandaville, "Usurious Piety", 293-4; Singer, Constructing Ottoman Beneficence, h. 18.

21 Dalam tulisan ini, peneliti menggunakan edisi terjemahan, yaitu Muhammad Abid Abdullah Al-Kabisi, Hukum Wakaf (Jakarta Dompet Dhuafa \& IIMan, 2004).

22 Muhammad Abid Abdullah Al-Kabisi, Hukum Wakaf, h. 263-264.

23 Muhammad Abid Abdullah Al-Kabisi, Hukum Wakaf, h. 266-267.

24 Muhammad Abid Abdullah Al-Kabisi, Hukum Wakaf, h. 268.

25 Dikutip dalam Kementrian Agama, Pedoman Pengelolaan Wakaf Tunai (Jakarta: Direktorat Pemberdayaan Wakaf, Direktorat Jenderal Bimas Islam, Kementerian Agama, 2014), h. 16.

26 Lihat Robert W. Hefner, "Islam, State, and Civil Society: ICMI and the Struggle for the Indonesian Middle Class”, Indonesia, No. 56 (Oct., 1993), h. 1-35.

27 Lihat misalnya Gregory C. Kozlowski, Muslim Endowment and Society in India (Cambridge: Cambridge University Press, 1985).

28 Siti Mashitoh Mahamood, Waqf in Malaysia: Legal and Administrative Perspective (Kuala Lumpur: University of Malaya Press, 2006); compare with Abdul Azis bin Muhammad, Zakat and Rural Development in Malaysia (Kuala Lumpur: Berita Publishing, 1993).

29 Arskal Salim, "The Influential Legacy of Dutch Islamic Policy on the Formation of Zakat (Alms) Law in Modern Indonesia," Pacific Rim Law $\mathcal{E}$ Policy Journal Association, Vol. 15, No. 3 (2006), 683-701; Amelia Fauzia, Faith and the State: the History of Islamic Philanthropy in Indonesia, a Ph.D. Thesis at the Asia Institute, the University of Melbourne, 2009.

30 Norbert Oberauer, "Fantastic Charities": The Transformation of Waqf Practice in Colonial Zanzibar," Islamic Law and Society, 15, (2008), h. 315. 
31 Amelia Fauzia, Faith and the State, h. 102-4.

32 Untuk diskusi lebih jauh baca Rakhmat Djatnika, "Les wakaf ou 'bien de mainmorte’ aİ Java-est: eitude diachronique,” Archipel (1985), h. 121-136.

33 Abdurrahman, Masalah Perwakafan Tanah Milik dan Kedudukan tanah Wakaf di Negara Kita (Jakarta: PT Citra Aditya Bakti, 1990), h. 18-20.

34 Lihat Undang-undang No 5 Tahun 1960 tentang Undang-undang Pokok Agraria, Bab XI pasal 49.

35 UU No 41 Tahun 2004.

36 Lihat UU No 41 Tahun 2004 tentang Wakf dan jug abaca Jaih Mubarok, Wakaf Produktif (Bandung: Simbiosa Rekatama Media, 2008), h. 57-9.

37 Untuk dapat dilaksanakan secaea operasional, pemerintah juga mengeluarkan Perpu (Peraturan Pemerintah) No 42 Tahun 2006 tentang pelaksanaan wakaf.

38 Hari Chandra \& Asmak A. B. Rahman, "Waqf Investment: A Case Study of Dompet Dhuafa,” Shariah Journal, Vol. 18, No. 1 (2010), h. 163-190.

39 Hari Chandra \& Asmak A. B. Rahman, "Waqf Investment: A Case Study of Dompet Dhuafa," 183.

40 Muhyar Fanani, "Pengelolaan Wakaf Tunai," h. 181.

41 http://www.republika.co.id/berita/dunia-islam/islam-nusantara/09/11/24/ 91209-waqf-fund-canangkan-program-sejuta-wakif

42 Wawancara dengan Guntur S. Mahardika, Oktober 2010.

43 Lihat Hilman Latief, Politik Filantropi Islam: Negara, Pasar dan Masyarakat Sipil (Yogyakarta: Ombak, 2013), khususnya bab 4.

44 http://hizbut-tahrir.or.id/2014/02/04/hukum-wakaf-tunai/

45 Perbincangan dengan peneliti bulan Maret 2015.

46 http://www.fujamas.net/index.php/berita/berita-islam-solo-raya/209-pdmmuhammadiyah-karanganyar-luncurkan-wakaf-tunai.html (Diakses 1 Febrauri 2015)

47 http://www.muhammadiyah.or.id/muhfile/download/10_Bambang\%20Setiaji.pdf

48 http://lumbungwakaf.blogspot.com/p/profile-lumbung-wakaf-nahdlatululama.html

49 Ahmad Furqon, "Analisis Praktek Perwakafan Uang Pada Lembaga Keuangan Syariah," Walisongo, Volume 19, Nomor 1 (Mei 2011), h. 169-170.

\section{Daftar Pustaka}

Abdurrahman. 1990. Masalah Perwakafan Tanah Milik dan Kedudukan tanah Wakaf di Negara Kita (Jakarta: PT Citra Aditya Bakti).

Abu Bakar, Irfan.2009. "Cash Waqf in Classical and Present-day Fiqh Discourse," Kultur, Vol. 4, Number 1, 2009, 121-134.

Al-Kabisi, Muhammad Abid Abdullah. Hukum Wakaf(Jakarta Dompet Dhuafa \& IIMan, 2004)

Chaider S. Bamualim (ed.). 2006. Islamic Philanthropy $\mathcal{E}$ Social Development in Contemporary Indonesia (Jakarta: CRCS UIN Syarif Hidayatullah). 
.2005. Studi Kasus dan Lembaga Wakaf dan Zakat di Indonesia (Jakarta: Center for the Study of Religion and Culture (CSRC), UIN Syarif Hidayatullah) . 2005. dan Irfan Abubakar (eds.), Revitalisasi Filantropi Islam: Studi Kasus Lembaga Wakaf dan Zakat di Indoensia (Jakarta: Center for the Study of Religion and Culture (CSRC), UIN Syarif Hidayatullah).

(eds.). 2006. Filantropi Islam dan Keadilan Sosial (Jakarta: CSRC).

Chandra, Hari \& Rahman, Asmak A. B. 2010. "Waqf Investment: A Case Study of Dompet Dhuafa," Shariah Journal, Vol. 18, No. 1 (2010) 163-190.

Cizakca, Murad. 1995. "Ottoman Cash Waqfs Revisited: the Case of Bursa 1555 1823," Journal of the Economic and the Social History of the Orient, 38, 3.

-2000. An History of Islamic Foundations in the Islamic World from the Seventh Century to the Present (Istanbul: Bogazici University Press).

Departemen Agama RI. 2008. Strategy Pengembangan Wakaf Tunai di Indonesia (Jakarta: Direktorat Pemberdayaan Wakaf)

Djatnika, Rakhmat. 1985. "Les wakaf ou 'bien de mainmorte’ aÌ Java-est: eitude diachronique," Archipel, 121-136

Fanani, Muhyar. 2010. "Pengelolaan Wakaf Tunai," Walisongo, Volume 19, Nomo 1, Mei, 179-195

Fauzia, Amelia. 2009. "Faith and the State: the History of Islamic Philanthropy in Indonesia”, PhD Dissertation, the University of Melbourne, Melbourne-Australia.

Furqon, Ahmad. 2011. "Analisis Praktek Perwakafan Uang Pada Lembaga Keuangan Syariah,” Walisongo, Volume 19, Nomor 1, Mei, 157-178.

Hefner, Robert W. 1993. "Islam, State, and Civil Society: ICMI and the Struggle for the Indonesian Middle Class”, Indonesia, No. 56 (Oct., 1993), pp. 1-35

Khan, Arif Ali at al. (eds.). 2006. Encyclopaedia of Islamic Law: Law of Waqf in Islam (New Delhi: Pentagos Press).

Kozlowski, Gregory C.1985. Muslim Endowment and Society in India (Cambridge: Cambridge University Press).

Latief, Hilman. 2010. Melayani Umat: Filantropi Islam dan Ideologi Kesejahteraan Kaum Modernis (Jakarta: Gramedia).

2013. Politik Filantropi Islam: Negara, Pasar dan Masyarakat Sipil (Yogyakarta: Ombak).

- 2010. "Health Provision for the Poor: Islamic Aid and the Rise of Charitable Clinics in Indonesia," Journal of Southeast Asia Research, 18, 3 (September 2010), 503-553

-2011. "Symbolic and Ideological Contestation over Humanitarian Emblems: The Red Crescent Movement in Islamizing Indonesia, Studia Islamika vol. 18, no. 2 (2011), 249-286.

Mahamood, Siti Mashitoh. 2006. Waqf in Malaysia: Legal and Administrative Perspective (Kuala Lumpur: University of Malaya Press).

Muhammad, Abdul Azis bin. 1993. Zakat and Rural Development in Malaysia (Kuala Lumpur: Berita Publishing).

Majelis Ulama Indonesia. Hasil Ijtima’ Ulama Komisi Fatwa se-Indonesia III, 1430 H/ 
2009 M.

Mandaville, Jon E. 2005. "Usurious Piety: The Cash Waqf Controversy in the Ottoman Empire," International Journal of Middle East Studies, No. 10 (1979).PIRAC, Muslim Philanthropy: Potential ad Reality of Zakat in Indonesia (Depok: Piramedia).

. 2002. Investing in Our Selves: Giving and Fundraising in Indonesia (Jakarta: Asian Development Bank).

Maimunah, Maya. 2011. "Peran Wakaf Tunai dalam Pemberdayaan Usaha Kecil dan Menengah di Tabung Wakaf Indonesia, Skripsi, UIN Syarif Hidayatullah.

Nasution, Mustafa Edwin dan Uswatun Hasanah (eds.). 2005. Wakaf Tunai, Inovasi Finansial Islam: Peluang dan Tantangan dalam Mewujudkan Kesejahteraan Ummat (Jakarta: PKTTI-UI, 2005), 51-78.

NCRP (National Committee for Responsive Philanthropy). 2003. "Understanding Social Justice Philanthropy," April 2.

Oberauer, Norbert. 2008. "Fantastic Charities": The Transformation of Waqf Practice in Colonial Zanzibar," Islamic Law and Society, 15, (2008), 315-370.

Payton, Robert L. and Michael P. Moody. 2008. Understanding Philanthropy: Its Meaning and Mission (Bloomington and Indianapolis).

Rozalinda. 2012. "Manajemen Risiko Investasi Wakaf Uang,” ISLAMICA, Vol. 6, No. 2, Maret 2012, 300-315.

Saidi, Zaim et al. (eds.). 2003. Pola Penggalangan Dana Sosial di Indonesia: Pengalaman Delapan Belas Lembaga Sosial (Jakarta: Piramedia, PIRAC \& Ford Foundation).

Salim, Arskal.2006. "The Influential Legacy of Dutch Islamic Policy on the Formation of Zakat (Alms) Law in Modern Indonesia,” Pacific Rim Law EO Policy Journal Association, Vol. 15, No. 3 (2006), 683-701.

Shaw, Aileen. 2002. "Social Justice Philanthropy: An Overview," The Synergos Institute, August 5.

Singer, Amy. 2002. Constructing Ottoman Beneficence: An Imperial Soup Kitchen in Jerusalem (Albany: A State University of New York Press). 
14. JURNAL ILMU-ILMU KEISLAMAN AFKARUNA

CONTOH SERTFIKAT WAKAF TUNAI
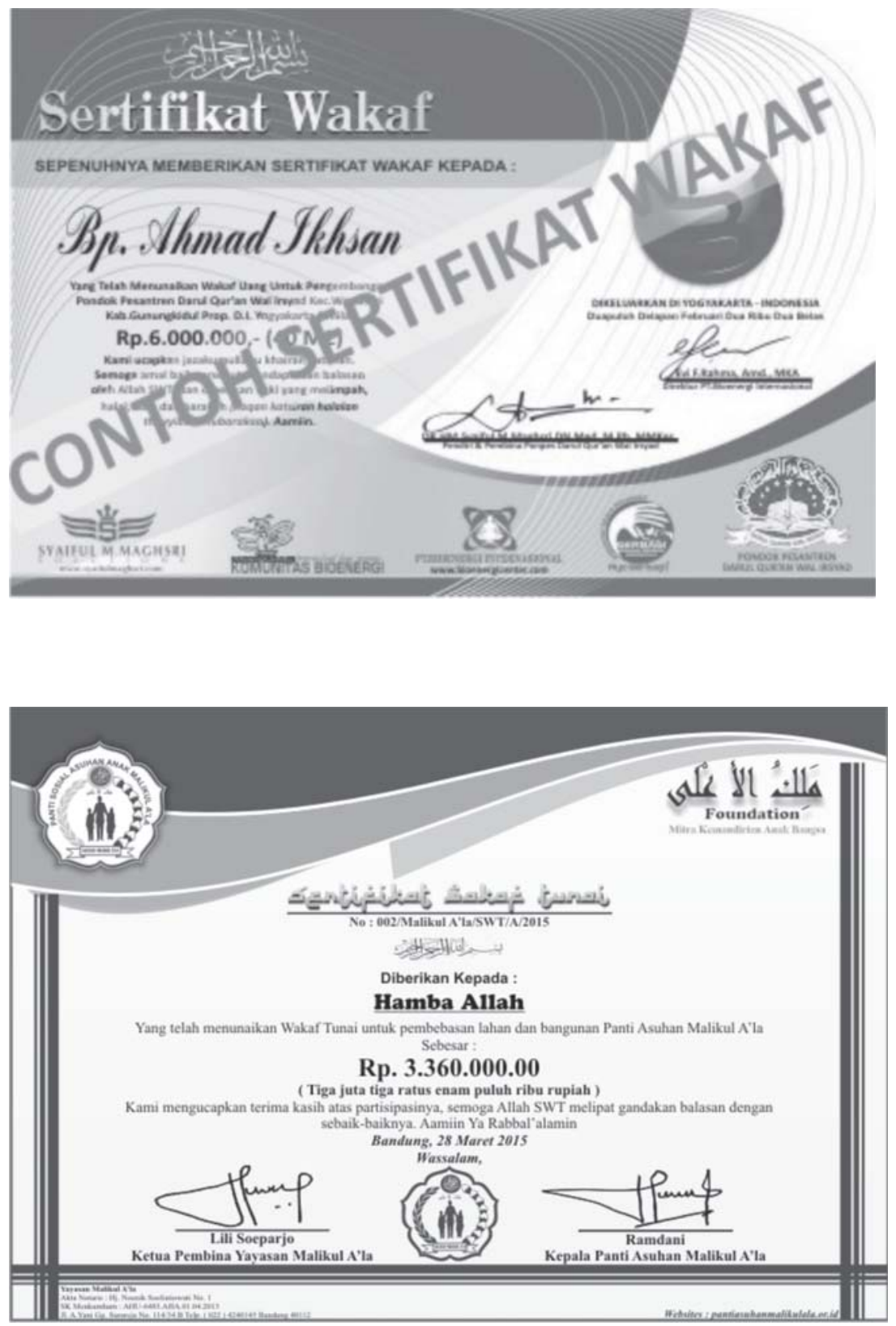


\section{SERTIFIKAT WAKAF No:A1-01}

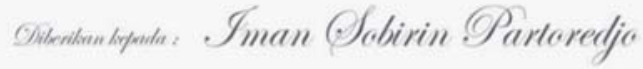

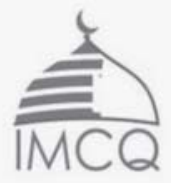

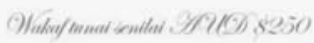

acn: 166195580

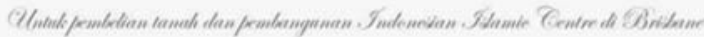

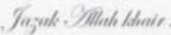

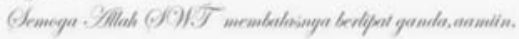

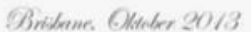

INDONESIAN MUSLIM CENTRE of QUEENSLAND 